\title{
ASSESSMENT OF INDOOR AND OUTDOOR RADON CONCENTRATIONS IN TALYSH, AZERBAIJAN
}

\author{
Feyzullayev A.A., Aliyev Ch.S., Baghirli R.J., Mahmudova F.F. \\ Institute of Geology and Geophysics, Azerbaijan National Academy of Sciences \\ 119, H.Javid Ave., Baku, Azerbaijan, AZ1143: radiometry@gia.science.az
}

Keywords: radon volume activity, radon danger, Talysh, thermal waters, people's health life expectancy
Summary. The article describes the results of modern radiation monitoring of the environment conducted in the Talysh region of Azerbaijan. Radiometric studies covered five districts of the Talysh region: Masalli, Lyankyaran, Astara, Yardimli and Lerik. Radiometric studies have monitored the level of radon concentrations in residential areas and in water. Measurements of radon volume activity in residential buildings were carried out in settlements of the studied region. The radon volume activity in residential areas was measured with radon Scout and radon Scout Plus radiometers from SARAD. The volume activity of radon in water was estimated using RAD7 (DURRIDGE) radiometers. A MKS-AT1125 dosimeter-radiometer was used to determine the radiation level. Indoor radon volume activity in the Talysh district ranges from 20 to $660 \mathrm{~Bq} / \mathrm{m}^{3}$. Based on the data obtained, maps of the distribution of radon volume activity are constructed separately for each region. According to these maps, the Lerik region, known for its long-livers, is characterized by relatively high levels of radon. Studies have shown that there is a definite correlation between radon levels in dwellings and life expectancy. The radon content in thermal waters varies very widely from $8.34 \mathrm{~Bq} / \mathrm{l}$ to $93.3 \mathrm{~Bq} / \mathrm{l}$. According to sanitary and hygienic standards for radon content, thermal waters of Talysh are not dangerous for people's health when taking baths and using them as drinking water, except for the Buludul source in Yardimli district. The content of radon in the water of this source exceeds the maximum permissible concentration for drinking water $(60 \mathrm{~Bq} / \mathrm{l})$ by more than 1.5 times.

(C) 2021 Earth Science Division, Azerbaijan National Academy of Sciences. All rights reserved.

\section{Introduction}

According to the International Committee on Radiation Protection, 40-75\% of total human exposure to natural radioactive sources comes from radon and its decay products. In 1987 radon and its decay products were classified by the International Agency for Research on Cancer as being carcinogenic to humans. Researches conducted in Europe and USA showed that radon is the second cause after smoking providing lung cancer diseases (Cohen, 1993). Radon is the main factor of lung cancer among non-smokers (Calabrese, Baldwin, 2002). Protecting people from exposure to the radioactive natural gas radon and its decay products is a national problem and requires the study of a number of issues related to the source of radon and the presence of radon in buildings.

Indoor radon studies in Azerbaijan were carried out for the first time in 2010-2011 by Institute of Geology and Geophysics of Azerbaijan National Academy of Sciences. These studies were conducted with the financial support of the Swiss National Science
Foundation. In 2014-2015 the investigation of radon problem in Azerbaijan was continued in the framework of Azerbaijan State Program (2014-2018). A study of the radon problem in Azerbaijan shows that its distribution in space is uneven and mosaic in nature.The regions with the highest concentrations are confined to the mountainous folded massifs of the G.Caucasus and Talysh, while those with the lowest concentrations are confined to the lowlands (Aliyev et al., 2017). The main objective of the study was to assess the results of the current monitoring of the radiation situation in the Talysh region and the correlation analysis between the life expectancy of the population and radon levels in their places of residence, as well as to develop measures for reducing the risk of radon emissions on a case-by-case basis.

\section{Materials and methods}

Radiometric work in the study area included measurements of the radon volume activity in residential premises and in the water of mineral springs 
which water is used by local residents, as well as measurements of radiation levels in the environment. Radon volume activity in residential areas was measured with Radon Scout and Radon Scout Plus radiometers from SARAD. They were installed in residential premises for several days. Radon volumetric activity in soil and water was measured by using RAD7 radiometers (DURRIDGE). The radiation level was measured by using dosimeter radiometer MKC-AT1125. Based on the averaged values of the data obtained, maps of the distribution of radon volume activity over the districts of the region under study were constructed. Maps were produced by using the Surfer program (production of Golden Software).

\section{Results and discussion}

Indoor radon. Radiometric studies had covered five districts of the Talysh region: Masalli, Lyankyaran, Astara, Yardimli and Lerik. As mentioned above, measurements of radon volume activity in residential buildings were carried out in in the human settlements of the study area. Indoor radon concentrations are measured in the living rooms of houses at ground level. Regarding the recruitment of participants, priority was given to older buildings by randomly selecting 3-5 dwellings in each area. Most of the houses inspected were built 30-50 years ago using bricks made of cement and sand and cemented floors. In Masalli district, studies were carried out in 17 settlements. The radon concentration here varied within $20-170 \mathrm{~Bq} / \mathrm{m}^{3}$. In 38 surveyed settlements of Lyankyaran district radon concentration varied within $20-600 \mathrm{~Bq} / \mathrm{m}^{3}$. In the Astara district, research was carried out in 23 localities. The radon concentration here varied within $50-190 \mathrm{~Bq} / \mathrm{m}^{3}$. In Yardimli district 19 settlements were surveyed. The radon volume activity here varied within $50-730 \mathrm{~Bq} / \mathrm{m}^{3}$. In Lerik district, studies were conducted in 32 localities. The radon concentration here varied within $89-215 \mathrm{~Bq} / \mathrm{m}^{3}$. On the basis of the obtained data the map of distribution of radon volume activity for Talysh region has been constructed.

Fig. 1 shows the distribution of indoor radon in Talysh mountain area. According to this map, the Lerik region, known for its long-livers, is characterized by a relatively high level of radon. According to the current regulatory document, the indoor radon volume activity should not exceed $200 \mathrm{~Bq} / \mathrm{m}^{3}$. As can be seen from the Table 1, in villages where centenarians live, the level of indoor radon varies between $100-200 \mathrm{~Bq} / \mathrm{m}^{3}$, averaging about $150 \mathrm{~Bq} / \mathrm{m}^{3}$. According to the Arndt-Schultz physiological law, weak radon stimulation has an activating, moderate - normalizing, strong - suppressive, super-strong - suppressive and harmful effects on human health (Lackey, 1982) (Table 1).

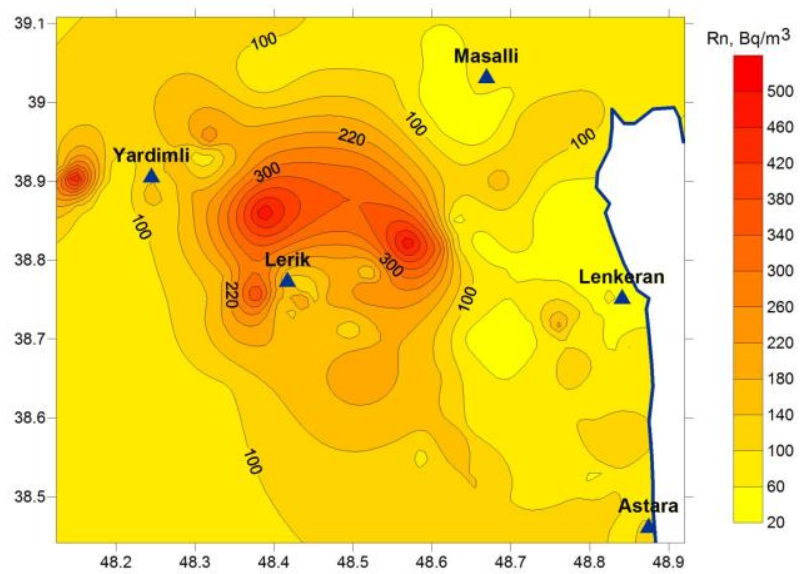

Fig. 1. Distribution of indoor radon volume activity in Talysh

Table 1

The average radon values in some villages of Lerik district of Talysh, where there are centenarians

\begin{tabular}{|l|c|c|}
\hline \multicolumn{1}{|c|}{ Vilages } & $\begin{array}{c}\text { Number of } \\
\text { dwellings }\end{array}$ & $\begin{array}{c}\text { Indor radon, } \\
\mathbf{B q} / \mathbf{m}^{3} \\
\text { (average data) }\end{array}$ \\
\hline Lerik & 4 & $125(101-140)$ \\
\hline Shingedulan & 4 & $127(111-143)$ \\
\hline Chayrud & 4 & $199(183-214)$ \\
\hline Bilaband & 4 & $113(97-128)$ \\
\hline Vizezemin & 4 & $115(109-131)$ \\
\hline Pirasora & 4 & $182(166-197)$ \\
\hline Barzavu & 4 & $200(181-217)$ \\
\hline Chanqamiran & 4 & $105(89-121)$ \\
\hline Average & & $\mathbf{1 4 7 . 6}$ \\
\hline
\end{tabular}

The relatively higher level of radon in residential buildings in Lerik district compared to other regions of Talysh can be seen more clearly in the presented histograms (Fig. 2).

Radon in mineral/thermal waters. Investigation of 9 natural emergences of water in 7 thermal springs provided a wide range of concentrations from 3.73 to $93.3 \mathrm{~Bq} / \mathrm{l}$. These mineral waters are classified as weak radon waters. According to sanitary and hygienic regulations, radon in the thermal waters of Talysh is not considered dangerous for people's health either by bathing or drinking, except for the Buludul spring. Radon volume activity in this spring exceeds the maximum permissible concentration for the drinking water $(60 \mathrm{~Bq} / \mathrm{L})$ by more than 1.5 times (Table 2). 


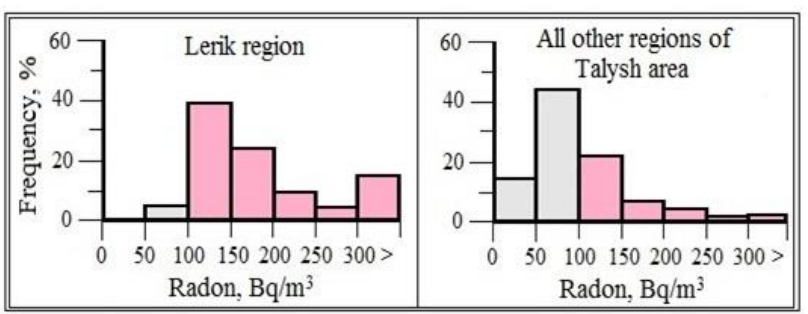

Fig. 2.Histograms of distribution of indoor radon values in Lerik and other regions of Talysh mountain area

\section{Conclusion}

The results of studies have shown that there is a certain correlation between radon levels in dwellings and longevity. However, this does not mean that radon can definitely be considered the main factor of longevity. Undoubtedly, a number of factors, such as climate, ecology, genetics and etc., contribute to this. To this complex we can also include that radon volume activity between $100-200 \mathrm{~Bq} / \mathrm{m}^{3}$ can have a positive effect on people's health and their life expectancy.

\section{Acknowledgment}

The presented work was supported by the grant project 6402 "Investigation of life quality and population longevity in Azerbaijan with higher natural radiation background" provided by Science and Technology Center in Ukraine, for which authors express their sincere appreciation.

Radon volume activity in thermal waters of Talysh

\begin{tabular}{|c|l|c|c|c|c|}
\hline \multirow{2}{*}{ № } & \multicolumn{1}{|c|}{ Spring } & \multirow{2}{*}{$\mathrm{R}, \mathrm{nSv} / \mathrm{h}$} & \multicolumn{3}{c|}{ Radon, Bq/L } \\
\cline { 4 - 6 } & & 116 & 3.73 & 0.834 & 2.62 \\
\hline 1 & Istisu (Masalli) & 118 & 7.51 & 2.99 & 5.95 \\
\hline 2 & Donuzuten (Masalli) & 121 & 8.64 & 8.35 & 8.5 \\
\hline 3 & Istisu (Astara) in emergence & 152 & 11.3 & 8.69 & 9.46 \\
\hline 4 & Istisu (Astara) focus & 76 & 11.6 & 9.01 & 10.1 \\
\hline 5 & Yanarbulaq (Astara) & 94 & 17.3 & 11.2 & 14.2 \\
\hline 6 & Istisu (Lyankyaran-Lerik) & 96 & 20.3 & 6.26 & 13.9 \\
\hline 7 & Yanardaq (Masalli) & 172 & 72.1 & 62.6 & 6 \\
\hline 8 & $\begin{array}{l}\text { Buludul (Yardimli) bottom } \\
\text { emergence }\end{array}$ & 178 & 93.3 & 86.1 & 90.6 \\
\hline 9 & Buludul (Yardimli) focus & & & \\
\hline
\end{tabular}

Correlation between radon concentrations in dwellings and longevity

\begin{tabular}{|c|c|c|}
\hline $\begin{array}{c}\text { Mean radon concentration } \\
\left(\mathrm{Bq} / \mathrm{m}^{3}\right)\end{array}$ & $\begin{array}{c}\text { Period of residence } \\
(\text { year })\end{array}$ & Number of people over 90 \\
\hline $20-100$ & $>40$ & 5 \\
\hline $100-200$ & $>40$ & 14 \\
\hline $200-300$ & $>40$ & 4 \\
\hline$>300$ & $>40$ & 1 \\
\hline
\end{tabular}

\section{REFERENCES}

Calabrese E.J., Baldwin L.A. Radiation Hormesis and cancer. Human and Ecological Risk Assessment, Vol. 8, No. 2, 2002, pp. 327-353.

Cohen B. Relationship between exposure to radon and various types of cancer. Health Physics, Vol. 65 (5), 1993, pp. 529-531.

Luckey T. Physiological benefits from low levels of ionizing radiation. Health Physics, Vol. 43, No. 6, 1982, pp. 771789.

Aliyev Ch.S., Feyzullaev A.A., Baghirli R.J, Mahmudova F.F. Regilarities of radon distribution on the territory of Azerbaijan and controlling factors. Geophysics, No. 1, 2017, pp. 7273 (in Russian).

\section{ЛИТЕРАТУРА}

Calabrese E.J., Baldwin L.A. Radiation Hormesis and cancer. Human and Ecological Risk Assessment, Vol. 8, No. 2, pp. 327-353.

Cohen B. Relationship between exposure to radon and various types of cancer. Health Physics, Vol. 65 (5), 1993, pp. 529-531.

Luckey T. Physiological benefits from low levels of ionizing radiation. Health Physics, Vol. 43, No. 6, 1982, pp. 771-789.

Алиев, Ч.С., Фейзуллаев, А.А., Багирли, Р.Дж., Махмудова, Ф.Ф. Закономерности распределения радона в Азербайджане и контролирующие их факторы. Геофизика, No.1, 2017, c. $72-73$. 


\title{
ОЦЕНКА КОНЦЕНТРАЦИИ РАДОНА ВНУТРИ И ВНЕ ЖИЛЫХ ПОМЕЩЕНИЙ В ТАЛЫШСКОМ РЕГИОНЕ (АЗЕРБАЙДЖАН)
}

\author{
Фейзуллаев А.А., Алиев Ч.С., Багирли Р.Дж.,Махмудова Ф.Ф. \\ Институт геологии и геофизики НАН Азербайджана \\ AZ1143, Баку, Азербайджан, просп. Г.Джавида, 119: radiometry@ gia.science.az
}

Pезюме. В статье описаны результаты современного радиационного мониторинга окружающей среды, проведенного в Талышском регионеАзербайджана. Радиометрические исследования охватили пять районов Талышской области: Масаллинский, Лянкяранский, Астаринский, Ярдымлинскийи Лерикский. При радиометрических исследованиях проведены мониторинги уровня концентрации радона в жилых помещениях. Измерения объемной активности радона в жилых домах проводились в населенных пунктах исследуемого региона. Объемную активность радона в жилых помещениях измеряли радиометрами Radon Scout и Radon Scout Plus от SARAD. Объемная активность радона в воде оценивалась с помощью радиометров RAD7 (DURRIDGE). Для определения уровня радиации использовался дозиметр-радиометр МКС-АT1125. Объемная активность радона внутри помещений в Талышском районе колеблется в пределах 20-660 Бк/м³. На основе полученных данных построена карта распределения объемной активности радона для Талышского региона. Согласно этой карте Лерикский район, известный своими долгожителями, характеризуется относительно высоким уровнем радона. Результаты проведенных исследований показали, что существует определенная корреляция между уровнем радона в жилищах и продолжительностью жизни. Содержание радона в термальных водах изменяется в широких пределах от 8.34 Бк/л до 93.3 Бк/л. По санитарно-гигиеническим нормам содержания радона термальные воды Талыша не представляют опасности здоровью населения при приеме ванн и использовании в качестве питьевой воды, за исключением источника Бюлюдюл в Ярдымлинском районе. В воде этого источника содержание радона более чем в 1.5 раза превышает предельно-допустимую концентрацию, принятую для питьевой воды (60 Бк/л).

Ключевые слова: объемная активность радона, радоновая опасность, Тальи, термальные воды, здоровье человека, продолжительность жизни

\section{TALIŞ REGİONUNUN (AZəRBAYCAN) YAŞAYIŞ Və QEYRİ-YAŞAYIŞ YERLəRİNDə RADON QAZININ KONSENTRASIYYASININ QIYMOTLONDIRİLMOSI}

Feyzullayev Ә.Ә., Đliyev Ç.S., Bağırı R.C., Mahmudova F.F. Azarbaycan Milli ElmlarAkademiyasinin Geologiya va Geofizika İnstitutu AZ1143, Bakl, Azorbaycan, H. Cavid prosp.,119: radiometry@gia.science.az.

Xülasə. Məqalədə Azərbaycanın Talış regionunda aparılan müasir radioekoloji monitorinqin nəticələri təqdim edilmişdir. Aparılmış radiometrik tədqiqatlar Talış bölgəsinin beş rayonunu-Masallı, Lənkəran, Astara, Yardımlı və Lerik rayonlarını əhatə etmişdir. Radiometrik tədqiqatlar zamanı yaşayıs rayonlarında radonun həcmu aktivliyinin səviyyəsi və su nümunələrinin radionuklid analizi aparılmışdır. Yaşayış binalarında radonun həcmi aktivliyinin ölçülməsi tədqiq olunan regionun yaşayış məntəqələrində aparılmışdır. Radonun yaşayıș sahələrində həcmi aktivliyinin səviyyəsi SARAD firmasının Radon Scout və Radon Scout Plus radiometrləri ilə ölçülmüşdür. Radonun suda həcmi aktivliyi RAD7 (DURRIDGE) radiometrləri ilə təyin edilmişdir. Radiasiya səviyyəsi MKC-AT1125 radiometri ilə ölçülmüşdür. Müəyyən olunmuşdur ki, Talış bölgəsinin yaşayış məntəqələrində radonun həcmi aktivliyi 20-660 Bk/m3 arasında dəyişir. Alınan məlumatlar əsasında Talış regionu üçün radonun həcmi aktivliyinin paylanması xəritəsi yaradılmışdır. Bu xəritəyə əsasən, uzunömürlüləri ilə tanınan Lerik bölgəsi radonun həcmi aktivliyinin nisbətən yüksək səviyyəsi ilə xarakterizə olunur. Aparılan tədqiqatların nəticələri göstərdi ki, yaşayış binalarında radon həcmi aktivliyinin səviyyəsi ilə əhali arasında müşahidə olunan uzunömürlülük halları arasında müəyyən korrelyasiya mövcuddur. Regionun termal sularında radonun həcmi aktivliyinin göstəriciləri $8.34 \mathrm{~Bq} / \mathrm{l}$-dən $93.3 \mathrm{bk} / \mathrm{l}$-ə qədər çox geniş hüdudlarda dəyişir. Alınmış nəticələrə əsasən Bülyüdül bulağından başqa Talışın termal sularının içməli su kimi və balneolgiyada istifadəsi heç bir təhlükə törətmir. Bülyüdül bulağında isə radonun həcmi aktivliyi içməli su üçün yol verilən maksimum yol verilən həddən (60 Bq/1) 1.5 dəfə çoxdu.

Açar sözlori: radonun həcmi aktivliyi, radon təhlükəsi, Talış, termal sular, insan sağlamlı̆̆l, ömür uzunluluğu 